Volume 8, No.6, November - December 2019

International Journal of Advanced Trends in Computer Science and Engineering

Available Online at http://www.warse.org/IJATCSE/static/pdf/file/ijatcse125862019.pdf

https://doi.org/10.30534/ijatcse/2019/125862019

\title{
Advanced Information Technology: Automated and Individual Learning Systems
}

\author{
Svetlana Pivneva $^{1}$, Diana Denisova ${ }^{2}$, Nataliaya Vitkovskaya ${ }^{3}$, Rafina Zakieva $^{4}$, Elena Muraya $^{5}$, \\ Galina Ushakova ${ }^{6}$ \\ ${ }^{1}$ Russian State Social University, Moscow, Russia \\ ${ }^{2}$ Russian State Social University, Moscow, Russia \\ ${ }^{3}$ Russian State Social University, Moscow, Russia \\ ${ }^{4}$ Kazan State Power Engineering University, Kazan, Russia \\ ${ }^{5}$ Far Eastern State Transport University, Khabarovsk, Russia \\ ${ }^{6}$ Admiral Makarov State University of Maritime and Inland Shipping, St. Petersburg, Russia
}

\begin{abstract}
The purpose of the article is to determine the essence and main characteristics of individual information technology learning systems automated based on information and communication technologies.

The article defines the essence of automated individual learning systems based on information and communication technologies, which represent a technology that automatically adjusts educational content according to the actual level of educational achievements of the student, which this technology determines, as well as their individual characteristics (age, pace, psychotype, etc.).

A comparative analysis of traditional learning systems and automated individual learning systems based on information and communication technologies has been carried out. The main advantages of individual learning systems have been characterized. The characteristics inherent in the vast majority of individual learning systems have been determined. The description of the main types of individual learning systems has been carried out. There are several indicators based on which, it is possible to determine whether a learning system is individual.

It is noted that now, individual learning systems only begin active development and gradual introduction - such systems are not yet widespread even in the developed countries of the world, undergoing experimental testing. In the future, individual learning systems will become the engine of development of new pedagogy, strategies for the personification of education, and expansion of opportunities for active learning.
\end{abstract}

Key words: individual learning system, personalized learning, individual educational trajectory, individual learning progress.

\section{INTRODUCTION}

Modern realities are characterized by significant changes in social life and rapid technical and technological development.
This contributes to the formation of the information society and the widespread use of information flows. An important feature of the modern information society is automation, which in the form of practical activities, certain measures, and technologies, aims at the use, storage, and processing of information, as well as its transfer, to achieve the objectives set by society. An important area of informatization and automation of society is informatization and automation of education, which allows increasing the effectiveness of all types of educational activities based on the use of information and computer technologies.

Individual learning systems (ILS) attracted the interest of researchers in the field of information and communication technologies (ICT) in education at almost all stages of development of this industry.

The possibilities of individualization in educational systems have grown significantly with the development of technology, webspace, and cloud computing. Although modern ILS are still in the process of an experimental study, they are gradually developed and implemented in the educational practice of various educational organizations. These systems are aimed at ensuring differentiation and personification of training at a higher quality level, compared to the systems of previous generations. The principles of their work are a dynamic adaptation to the level and subject of the course, due to the abilities, knowledge, and skills of the individual student. By "tracking" what the student knows, the system with a high degree of accuracy builds their educational route, consistently moving from one training block to the next one, until the planned results are achieved.

Considering that practical experience of ILS application, both in Russia and in the world as a whole, is rather insignificant. It is important to consider the conceptual bases of this technology for the avoidance of ambiguity of interpretations and approaches to understanding its essence and also features of development, introduction, and use. 


\section{LITERATURE REVIEW}

The works by authors such as V.P. Bespalko [1], S.V. Panyukova [2], M.P. Lapchik [3], I. Nepomnyashchikh [4], D. Fedyunin [5], T. Bakinova [6], N. Bondarenko [7], N. Demkina [8], R. Kuanysheva [9], and E. Avksentieva [10] are devoted to the study of the conceptual foundations of automation and informatization of education, as well as the analysis of the pedagogical potential of ICT use.

Using the capabilities of modern technologies in the individualization of education is considered in the studies by S.M. Avdeeva, L.L. Bosova [11], and O.A. Zimovina [12]. In particular, V.M. Trembach analyzed the features of intelligent ILS of open education [13]. A.V. Osin investigated the development of a global system of training and knowledge control using intelligent Internet technologies. The author highlights the modern problems of the theory and methods of designing intelligent ILS based on the latest web-technologies [14]. L.L. Bosova and A.Yu. Bosova carried out a comparative analysis of intellectual and ILS; prospects for the development of such systems based on the Internet were determined [15].

According to H. Aguinis and K. Kraiger [16], individual learning technologies are specialized software or services that adapt to the needs of individual students in the course of learning. These tools can synchronize with the learning process, adapt to the progress of each student based on machine learning (ML) technologies and independently adjust the learning content in real-time. According to the authors, ILS aims to informationally support the user in choosing a training course, training topics and training materials, lectures, online discussions, etc.

The main approaches to the development of automated ILS proposed by the authors are presented in Table 1 .

Table 1: Approaches to the development and basic functions of automated ILS

\begin{tabular}{|c|c|c|}
\hline Architects & Year & Description of the use of the approach and basic functions of the system \\
\hline Bell B.S., Kozlowski S.W.J. [17] & 2002 & $\begin{array}{l}\text { User behavior modeling in the network to improve the navigation of online } \\
\text { resources to find relevant resources with the use of reference labels }\end{array}$ \\
\hline $\begin{array}{l}\text { DeRouin R.E., Fritzsche B.A., Salas E. } \\
{[18]}\end{array}$ & 2004 & $\begin{array}{l}\text { Based on registration information, the system recommends training materials or a } \\
\text { particular type of professional activity }\end{array}$ \\
\hline $\begin{array}{l}\text { Drachsler H., Hummel H., Koper R. } \\
\text { [19] }\end{array}$ & 2008 & $\begin{array}{c}\text { The system is an extension of the educational web-based system with support for } \\
\text { personality-oriented learning functions }\end{array}$ \\
\hline Tan H., Guo J., Li Y. [20] & 2008 & $\begin{array}{l}\text { The system uses the theory of fuzzy answers for the initial accumulation of } \\
\text { student preferences. Such a system correlates students with training courses at } \\
\text { different difficulty levels }\end{array}$ \\
\hline $\begin{array}{c}\text { Bobadilla J., Serradilla F., Hernando A. } \\
\text { [21] }\end{array}$ & 2009 & $\begin{array}{l}\text { The system makes it possible to evaluate training courses in terms of their } \\
\text { complexity and relevance to the student's career goals. Supports the process of } \\
\text { social navigation }\end{array}$ \\
\hline $\begin{array}{l}\text { Verbert K., Duval E., Lindstaedt S.N., } \\
\text { Gillet D [22] }\end{array}$ & 2010 & $\begin{array}{l}\text { The rules of identifying pedagogically oriented connections between the } \\
\text { characteristics of the student and the characteristics of their educational activity } \\
\text { are proposed }\end{array}$ \\
\hline $\begin{array}{l}\text { Thai-Nghe N., Drumond L., } \\
\text { Krohn-Grimberghe A., } \\
\text { Schmidt-Thieme L. [23] }\end{array}$ & 2010 & $\begin{array}{l}\text { The system is based on the process of extracting knowledge from the history of } \\
\text { the use of web resources }\end{array}$ \\
\hline Kong X., Boll S., Heuten W. [24] & 2013 & $\begin{array}{l}\text { A technical solution to the problem of a personalized search for educational } \\
\text { objects in web services is presented based on a comparison of the characteristics } \\
\text { of the user and the corresponding object }\end{array}$ \\
\hline $\begin{array}{l}\text { Hoic-Bozic N., Holenko Dlab M., } \\
\text { Mornar V. [25] }\end{array}$ & 2015 & $\begin{array}{c}\text { The system allows teachers to choose a learning pattern and determines the best } \\
\text { learning strategy }\end{array}$ \\
\hline $\begin{array}{c}\text { Bokde D.K., Girase S., Mukhopadhyay } \\
\text { D. [26] } \\
\end{array}$ & 2016 & The system provides recommendations for the formation of the learning goal \\
\hline $\begin{array}{l}\text { Hasan M., Ahmed S., Abdullah D.M., } \\
\text { Rahman M.S. [27] }\end{array}$ & 2016 & $\begin{array}{l}\text { The system allows carrying out the best selection of the teacher for the effective } \\
\text { achievement of the chosen educational purpose }\end{array}$ \\
\hline
\end{tabular}


Along with this, the analysis of the concept of automated ILS and the experience of their use in the learning system of information technology specialists as the main subjects of innovation in modern society is not presented in the scientific and pedagogical space.

Research hypothesis: The scientifically grounded and pedagogically expedient introduction of modern ICT into the educational environment, in particular, ILS based on information technologies, will promote acquisition by this environment of signs of openness and personification that will make possible access to qualitative educational content to all subjects of training.

\section{PROPOSED METHODOLOGY}

\subsection{General description}

A set of theoretical and empirical methods was applied to achieve the research goal:

theoretical methods - analysis, systematization, generalization of works of Russian and foreign researchers and experts in the field of creation and use of modern means of automation of educational process to determine the content of the basic concepts, advantages, and characteristics of the

ILS, highlight the indicators that determine whether the learning system is adaptive; matching and comparing establishing differences between traditional and individual systems of learning based on ICT;

empirical methods - an online expert survey with representatives of Russian universities (30 universities - 30 experts), competent in the use of automated ILS in institutions where they work (heads of technical departments, specialists in informatization of institutions, etc.).

\subsection{Algorithm}

At the first stage of the study, the analysis of scientific literature on the use of automated ILS was carried out.

At the second stage of the study, a comparison was made between the traditional learning system and automated ILS, the main characteristics of ILS were determined, a description of the main types of ILS was presented, and indicators were identified, by which it was possible to determine whether the training system was individual.

\subsection{Flow chart}

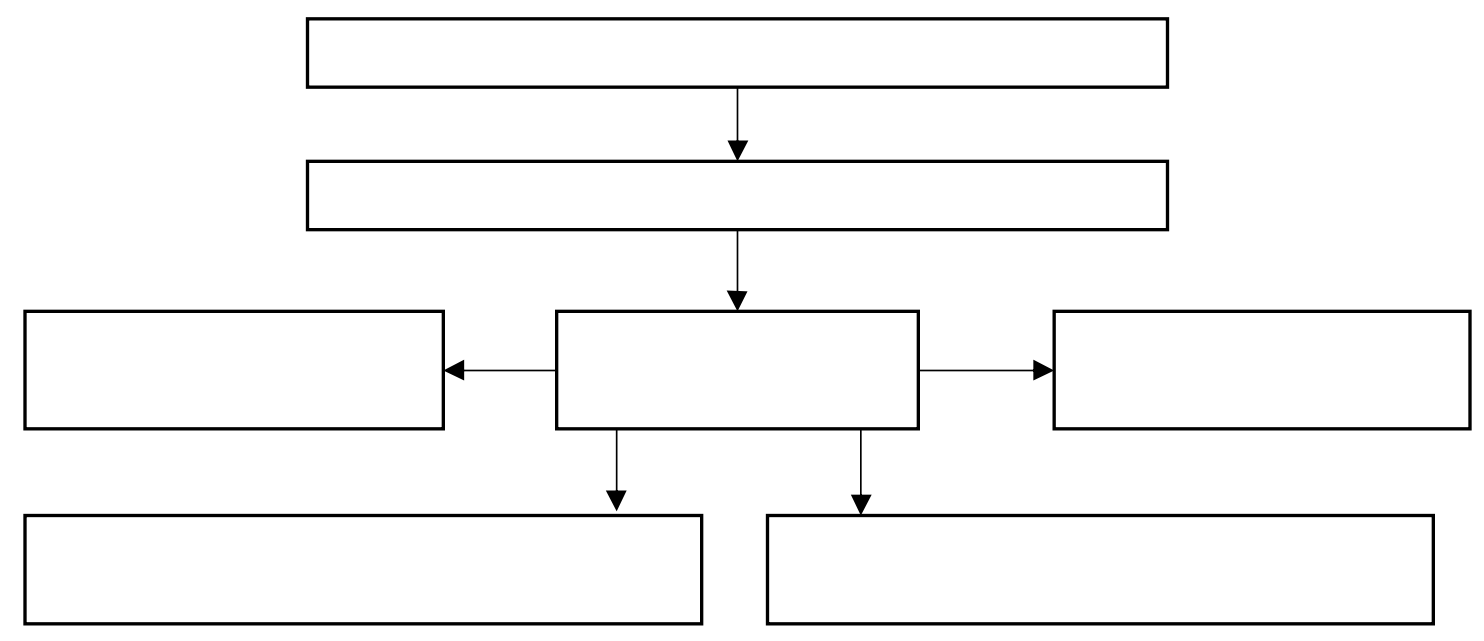

\section{RESULT ANALYSIS}

Experts believe that although most modern ICT-based learning support systems can significantly differentiate and individualize the educational process, this is not evidence of their attribution to ILS. Usually, these systems are able to build a more or less correct individual educational route for the student based on simple data and allow achieving a certain differentiation of the educational process with or without the participation of the teacher. At the same time, as experts point out, ILS are platforms with flexible evaluation algorithms and the ability to obtain data on performance and build accurate conclusions on their basis. They involve tracking the individual progress of each student and using this data to dynamically change the content in real-time. In other words, ILS is more dynamic and accurately "adapt" to each student, their pace, age, psychological and other characteristics, selecting the appropriate accompaniment and content.

Table 2 presents the comparative characteristics of traditional and automated ILS based on the expert survey. 
Table 2: Comparative characteristics of the traditional learning system and automated ILS based on ICT

\begin{tabular}{|c|c|}
\hline Traditional system of education based on ICT & Automated ILS based on ICT \\
\hline Episodic tracking of learning outcomes & Careful monitoring of the educational progress of students at all stages \\
\hline $\begin{array}{c}\text { Tracking the results of test control, statistics of time } \\
\text { spent, etc. }\end{array}$ & $\begin{array}{c}\text { Tracking the complexity of the material, the success of such tasks, the } \\
\text { readiness of students to perceive new material, the progress of their abilities } \\
\text { in time, etc. }\end{array}$ \\
\hline Fixing what students have accomplished & Fixing in detail what students know \\
\hline Focus on learning & Focus on understanding \\
\hline $\begin{array}{c}\text { Accounting for the level of knowledge on various } \\
\text { topics/sections/modules, etc., "selection" and "dosage" } \\
\text { of material, taking into account the identified level of } \\
\text { knowledge }\end{array}$ & $\begin{array}{c}\text { Accounting for the level of knowledge and skills in the "setting" of } \\
\text { content parameters; assessing the sensitivity of students to changes (in } \\
\text { teaching, pace, etc.); assessing the strengths and weaknesses of students and } \\
\text { the corresponding adjustment of goals; anticipating the speed and } \\
\text { probability of achieving goals, a certain level of knowledge, etc. to find the } \\
\text { optimal strategy for each student at each level }\end{array}$ \\
\hline $\begin{array}{c}\text { Formation of assumptions that lead to an increase in } \\
\text { error with each subsequent level of training }\end{array}$ & $\begin{array}{c}\text { Formation of conclusions and recommendations, the accuracy of which } \\
\text { increases with each next level of training }\end{array}$ \\
\hline
\end{tabular}
Note: Compiled on the basis of the expert survey

According to experts, there are many forms of ILS. Although there is no unambiguous gradation and description of such systems in the educational industry, experts suggest that they can be described by the following characteristics, which will be inherent in the vast majority of them (Table 3 ).

Table 3: Main characteristics of ILS

\begin{tabular}{|c|c|c|c|}
\hline No. & Characteristic & Essence & $\% *$ \\
\hline 1 & automatization & $\begin{array}{l}\text { ability to create automated processes that reduce the number of routine operations in the } \\
\text { assessment, training, and achievement of training goals }\end{array}$ & $93 \%$ \\
\hline 2 & seq & $\begin{array}{l}\text { ability to ensure the consistent progression of student competencies defined in the end goals } \\
\text { into a fixed or non-fixed unit of time }\end{array}$ & $87 \%$ \\
\hline 3 & eval & $\begin{array}{l}\text { possibility of applying some criteria, diagnostic and formative assessment based on greater } \\
\text { immediacy and continuity }\end{array}$ & $87 \%$ \\
\hline 4 & $\begin{array}{l}\text { real-time data } \\
\text { collection }\end{array}$ & $\begin{array}{l}\text { ability to collect, compute, and evaluate data from an array of resources using specific methods } \\
\text { in real-time or near-real-time }\end{array}$ & $83 \%$ \\
\hline 5 & self-organization & $\begin{array}{l}\text { ability of the system to use the results for the continuous formation of feedback cycles } \\
\text { (feedbacks) in the process of teaching and learning }\end{array}$ & $80 \%$ \\
\hline
\end{tabular}

Note: compiled on the basis of the expert survey; ${ }^{*}$ - percentage of expert mentions.

Taking into account these characteristics, experts identified four main types of ILS (Table 4).

Table 4: Main types of ILS

\begin{tabular}{|l|l|l|}
\hline No. & ILS type & $\% *$ \\
\hline 1 & ML-based ILS & $90 \%$ \\
\hline 2 & ILS based on the Progressive Algorithm & $83 \%$ \\
\hline 3 & Rule-based ILS & $83 \%$ \\
\hline 4 & ILS based on Decision Tree & $80 \%$ \\
\hline
\end{tabular}

Note: compiled on the basis of the expert survey; * percentage of expert mentions.

\section{DISCUSSION}

Speaking about the ML-Based ILS, experts primarily noted that, in a general sense, ML is a sub-branch of artificial intelligence in the field of computer science, which often uses statistical techniques to provide computers with the ability to learn on the basis of the data obtained, that is, gradually improve performance in the course of solving a specific problem without being explicitly programmable. According to one of the experts, "It is possible to say that machine learning occurs when it changes the structure, program, or data (in response to external information) in such a way that its expected future performance improves".

According to experts, ML-based ILS is the most up-to-date science-oriented means of ensuring genuine individuality of learning. ILS, based on ML use programmed algorithms to predict student learning progress in real-time. Such ILS uses learning algorithms to create other algorithms, which in turn create predictive analytics that can continuously collect data and apply it to advance the student along the educational route $[11,12]$.

Experts believe that the main characteristics of the ML-based ILS are the following (Table 5). 
Table 5: Main characteristics of ML-based ILS

\begin{tabular}{|c|c|c|c|c|}
\hline No. & Characteristic & Content & $\%^{*}$ & Rank \\
\hline 1 & $\begin{array}{c}\text { Continuous and dynamic } \\
\text { improvement }\end{array}$ & teaching methodology improves over time & $93 \%$ & 1 \\
\hline 2 & Student's profile & $\begin{array}{c}\text { contain classification information about students: learning style, } \\
\text { academic performance individual characteristics, strengths and } \\
\text { weaknesses, etc. }\end{array}$ & $90 \%$ & 2 \\
\hline 3 & $\begin{array}{c}\text { Educational route and pace of } \\
\text { learning }\end{array}$ & students are able to automate the process of learning & $87 \%$ & 3 \\
\hline 4 & $\begin{array}{c}\text { Individualized feedback } \\
\text { system can display data on the individual level of knowledge of the } \\
\text { student and provide accurate feedback, recommendations based on } \\
\text { general ideas about effective learning }\end{array}$ & $83 \%$ & 4 \\
\hline 5 & Content-agnostic & $\begin{array}{c}\text { system assumes relative knowledge about educational results, } \\
\text { achievements of the student, based on a variety of educational tools } \\
\text { (text, video, audio, etc.) }\end{array}$ & $80 \%$ & 5 \\
\hline
\end{tabular}

Note: compiled on the basis of the expert survey; ${ }^{*}$ - percentage of expert mentions.

ILS based on the Advanced Algorithm, according to experts, provides interaction between the computer and the student in the format "1:1" that is them scalable on type of contents (as a rule, exact sciences, including information technologies). Content modules are assigned ("opened") to specific, individual student profiles based on the pre-validated quality of knowledge and skills. That is if the student successfully passes module "A", it is recorded in their profile and then the system "picks up" the next module - "B".

According to experts, such systems provide feedback, evaluation of educational routes, and selection of educational content for the student in real-time, analyzing the data obtained from other students who have reached a similar level and study similar content. ILS based on the Progressive Algorithm records and manages huge amounts of data tied to student profiles and records different behaviors and activities: the number of clicks and time intervals, during which certain tasks were performed, unsuccessful and successful attempts to perform tasks, etc. In such systems, educational routes are determined in real-time and feedback is provided instantly in response to data that is continuously analyzed in the background. Training methods and educational content are changed to the alternative if the previously laid route turns out to be ineffective.

Rule-based ILS, according to experts, function based on a predetermined set of rules and, compared to systems based on ML, are less accurately adapted to each student. According to experts, such systems are not designed according to an algorithmic approach, but the choice of the educational route is determined by certain rules that may change for individual students; feedback is provided after the completion of the training module. Rule-based ILS does not use profile data regarding individual features and characteristics. Students take a pre-defined learning route with pre-defined sequences. Feedback is systematically provided and corrections are made based on a predefined set of rules.ILS based on Decision Tree, according to experts, represents a relatively simple classification ("tree") of a certain and limited repository of content, assessment, response bank. Typically, as experts specify, such systems have limited types of estimates, which are binary in form and function. However, ILS based on Decision Tree are different from Rule-based ILS because the rules are relatively static and do not change. Such systems do not use student profiles; instead, they use a series of "if this is true - then this it true" statistical sequences.

According to experts, systems based on Decision Tree, depending on their complexity, can take the form of intelligent systems, but are not knowledge-based, because they do not have the appropriate collective data collection. Such ILS uses an established set of rules from a predefined set of content modules, ratings, and response banks. Student workflows are created using data intervals and feedback.

Determining the advantages of ILS, experts highlight the following (Table 6).

Table 6: Main advantages of ILS

\begin{tabular}{|c|c|c|c|}
\hline No. & Advantage & $\%^{*}$ & Rank \\
\hline 1 & automation of assessment and forecasting, which significantly increases the efficiency of these \\
processes & $93 \%$ & 1 \\
\hline 2 & $\begin{array}{c}\text { ability to adapt to each student, regardless of the starting level of knowledge, abilities, features of } \\
\text { psychophysical development, etc., in contrast to the traditional system in which the student must } \\
\text { adapt to the general standards }\end{array}$ & $90 \%$ & 2 \\
\hline 3 & $\begin{array}{c}\text { regulation of the degree of complexity of educational content, which contributes to a more effective, } \\
\text { consistent passage of the course }\end{array}$ & $87 \%$ & 3 \\
\hline 4 & $\begin{array}{c}\text { possibility of continuous assessment, tracking of the educational progress of students and adjust it if } \\
\text { necessary }\end{array}$ & $83 \%$ & $4-5$ \\
\hline 5 & ability to obtain data not only on the progress of each student but also on their individual needs & $83 \%$ & $4-5$ \\
\hline
\end{tabular}




\begin{tabular}{|c|c|c|c|}
\hline 6 & $\begin{array}{c}\text { ability of the student to carry out introspection, track their educational route, progress in the learning } \\
\text { process by receiving feedback from the system in real-time }\end{array}$ & $80 \%$ & $6-7$ \\
\hline 7 & $\begin{array}{c}\text { encouraging students to self-develop and implement an individual educational trajectory } \\
\text { independently of the teacher, through automated feedback loops }\end{array}$ & $80 \%$ & $6-7$ \\
\hline 8 & $\begin{array}{c}\text { possibility of reducing the routine load on teachers, freeing up time for professional development, } \\
\text { etc. }\end{array}$ & $76.7 \%$ & 8 \\
\hline 9 & $\begin{array}{c}\text { possibility of continuous improvement of training courses on the basis of the deep analysis of } \\
\text { educational progress, features of the passing of an individual trajectory by each student that promotes } \\
\text { the improvement of quality of educational activity of institution as a whole }\end{array}$ & $73.3 \%$ & 9 \\
\hline
\end{tabular}

Note: compiled on the basis of the expert survey; * - percentage of expert mentions.

According to one expert, "ILS, regardless of their type, tend to need an architecture that integrates the key functions of modules (learning content), assessment, and competency frameworks, which together should support a personalized learning environment".
The analysis of the results of the expert survey allowed identifying several indicators that determine whether the learning system is individual. According to experts, it is possible to consider a learning system individual if it meets the following requirements (Table 7).

Table 7: Indicators of the learning system individuality

\begin{tabular}{|c|c|c|}
\hline No. & Indicator & $\% *$ \\
\hline 1 & Can adapt to different learning styles (e.g. different pace) & $93 \%$ \\
\hline 2 & $\begin{array}{c}\text { Contains statistically accurate cognitive models to determine and verify the validity of the achieved competence } \\
\text { level of students }\end{array}$ & $90 \%$ \\
\hline 3 & $\begin{array}{l}\text { Can correctly implement accurate and continuous real-time data collection regarding student success and use } \\
\text { this data to automatically adjust the educational route }\end{array}$ & $87 \%$ \\
\hline 4 & Contains functionality for individual evaluation & $83 \%$ \\
\hline 5 & Can accurately identify corrections and corrective actions through individual evaluation & $83 \%$ \\
\hline 6 & $\begin{array}{l}\text { Can simultaneously critically measure knowledge (how successfully the student has mastered the educational } \\
\text { content) and behavioral (how the student was actively involved in the learning process) components }\end{array}$ & $80 \%$ \\
\hline 7 & Can develop comprehensive competency frameworks that index learning outcomes & $76,7 \%$ \\
\hline
\end{tabular}

Note: compiled on the basis of the expert survey; ${ }^{*}$ - percentage of expert mentions.

Experts note that today, ILS are only beginning active development and gradual implementation. Such systems have not yet become widespread even in the developed countries of the world and are being tested experimentally. According to experts, ILS will become the engine of development of new pedagogy, strategies of personification of education, and expansion of opportunities of active training in the next few years.

\section{CONCLUSION}

Modern achievements in the development of technologies allow expanding the functionality of support for individual educational trajectories of students. ILS are specialized software or services adapted to the needs of individual students in the learning process. These tools can synchronize with the learning process, adapt to the progress of each student, and independently adjust the learning content in real-time.

Thus, the results of the study confirmed the hypothesis that the scientifically grounded and pedagogically expedient introduction of modern ICT into the educational environment, in particular, ILS in information technologies, will promote acquisition by this environment of signs of openness, personification that will make access to high-quality educational content possible for all subjects of training.

The main advantage of ILS is their ability to determine how a person learns, as well as providing accurate and timely feedback and improving learning outcomes. Given this, it seems relevant and promising to study the basics of ILS design in the professional training of specialists in the field of information technology as the main subjects of innovation in modern society.

\section{ACKNOWLEDGEMENT}

"The article was prepared as a part of the research work on the topic "Automated intellectual information management system (AIIMS) by a digital university. I. Digital faculty", carried out with the financial support of the Russian State Social University."

\section{REFERENCES}

1. V.P. Bespalko. Obrazovanie i obuchenie s uchastiem kompyuterov [Computer Education and Training] (Pedagogy of the third millennium). Moscow: Publishing House of the Moscow Psychological and Social Institute, p. 352, 2002.

2. S.V. Panyukova. IIspolzovanie informatsionnykh i kommunikatsionnykh tekhnologii $v$ obrazovanii [The use of information and communication technologies in education]: a textbook for student universities. Moscow: Academy Publishing Center, p. 224, 2010.

3. M.P. Lapchik. Modern problems of informatization of education: monograph. Omsk: Publishing house of OmGPU, p. 404, 2017. 
4. I.V. Nepomnyashchikh, O.S. Lazareva, A.A. Artemyev. Land Resource Management: Geoinformation Support of Internal Controlling. Journal of Environmental Management and Tourism, vol. 10(5), pp. 1084-1093, November 2019.

5. D.V. Fedyunin, V.V. Bezpalov, S.A. Lochan, V.V. Golovina, A.V. Ivanov. Information Support Model for the Children's Leisure and Tourism Industry within the Annual Planning Cycle. Journal of Environmental Management and Tourism, Vol. 9(6), pp. 1256-1262, February 2019.

https://doi.org/10.14505//jemt.9.6(30).15

6. T.I. Bakinova, N.E. Darbakova, G.Y. Kazakova, S.A. Sangadzhieva, I.E. Darbakova. Information Support of Monitoring as a Tool of Ecological Optimization of Agricultural Land Use. Journal of Environmental Management and Tourism, Vol. 10(1), pp. 195-201, May 2019.

7. N.G. Bondarenko, E.S. Getmanova, E.A. Kurenkova, E.M. Karaseva, O.V. Domnina, N.A. Grigorieva. Cloud Computing for Integrated Information-Analytical System of Educational Resources. International Journal of Innovative Technology and Exploring Engineering, Vol. 8(12), pp. 3578-3584, October 2019.

https://doi.org/10.35940/ijitee.L3793.1081219

8. N.I. Demkina, P.A. Kostikov, K.A. Lebedev. Formation of professional competence of future specialists in the field of information environment. Espacios, Vol. 40(23), p. 3, 2019.

9. R.S. Kuanysheva, M.I. Ragulina, A.Z. Asainova, M.P. Lapchik. Developing ICT Competences in Bachelors of Engineering and Technology in a Multilingual Environment. International Journal of Education and Practice, Vol. 7(3), pp. 123-135, 2019.

https://doi.org/10.18488/journal.61.2019.73.123.135

10. E.Y. Avksentieva, Y.A. Senterev, V.A. Kostezh, S.M. Platunova. Application of Cloud and Fog Computing in Educational Process upon Implementation of Master's Degree Program. International Journal of Engineering and Advanced Technology, Vol. 8(3), pp. 62-64, February 2019.

11. S.M. Avdeeva, L.L. Bosova, N.V. Nikulicheva, S.S. Khapaeva. Individualizatsiya obrazovatelnoi deyatelnosti obuchaemykh na osnove primeneniya elektronnogo obucheniya $\mathrm{s}$ ispolzovaniem distantsionnykh obrazovatelnykh tekhnologii. [Individualization of educational activities of students through the use of e-learning using distance learning technologies]. Moscow: FIED, p. 121, 2017.

12. O.A. Zimovina. Individualizatsiya obucheniya studentov $\mathbf{s}$ uchetom dominiruyushchikh u nikh kognitivnykh stilei. [Individualization of student learning, taking into account their dominant cognitive styles]. Sochi: Publishing House REC RAO, p. 254.

13. V.M. Trembach. Elektronnye obuchayushchie sistemy $\mathbf{s}$ ispolzovaniem intellektualnykh tekhnologii [E-learning system using intelligent technologies]. Otkrytoe obrazovanie, Vol. 4, pp. 52-62, 2013.

14. A.V. Osin. Otkrytye obrazovatelnye modulnye multimedia sistemy. [Open educational modular multimedia systems]. Moscow: Publishing Service, p. 328, 2010.

15. L.L. Bosova, A.Yu. Bosova, N.E. Zubchenok. Sozdanie i ispolzovanie elektronnykh obrazovatelnykh resursov dlya obshchego obrazovaniya [Creation and use of electronic educational resources for general education]: monograph. Moscow: MSPU, p. 192, 2014.

16. H. Aguinis, K. Kraiger. Benefits of Training and Development for Individuals and Teams, Organizations, and Society. Annual Review of Psychology, Vol. 60, pp. 451-474, 2009.
17. B.S. Bell, S.W.J. Kozlowski. Adaptive guidance: enhancing self-regulation, knowledge and performance in technology-based training. Personnel Psychology, Vol. 55, pp. 267-306, 2002. https://doi.org/10.1111/j.1744-6570.2002.tb00111.x

18. R.E. DeRouin, B.A. Fritzsche, E. Salas. Optimizing e-learning: research-based guidelines for learnercontrolled training. The Human Resource Management Review, Vol. 43(1), pp. 47-62, 2004.

https://doi.org/10.1002/hrm.20012

19. H. Drachsler, H. Hummel, R. Koper. Personal recommender systems for learners in lifelong learning: requirements, techniques and model. International Journal of Learning Technology, Vol. 3(4), pp. 404-423, 2008.

20. H. Tan, J. Guo, Y. Li. E-learning recommendation system. International Conference on Computer Science and Software Engineering, pp. 430-433, 2008.

21. J. Bobadilla, F. Serradilla, A. Hernando. Collaborative filtering adapted to recommender systems of e-learning. Knowledge-Based Systems, Vol. 22(4), pp. 261-265, 2009.

22. K. Verbert, E. Duval, S.N. Lindstaedt, D. Gillet. Context-aware recommender systems. Journal of Universal Computer Science, Vol. 16(16), pp. 2175-2178, 2010.

23. N. Thai-Nghe, L. Drumond, A. Krohn-Grimberghe, L. Schmidt-Thieme. Recommender System for Predicting Student Performance. Procedia Computer Science, Vol. 1, pp. 2811-2819, 2010.

24. X. Kong, S. Boll, W. Heuten. Towards recommender systems supporting knowledge sharing and transfer in vocational education and training. Second International Conference of E-Learning E-Technologies Education, pp. 25-30, 2013.

25. N. Hoic-Bozic, D.M. Holenko, V. Mornar. Recommender system and web 2.0 tools to enhance a blended learning model. The IEEE Transactions on Education, Vol. 59(1), pp. 48-70, 2015.

26. D.K. Bokde, S. Girase, D. Mukhopadhyay. An approach to a university recommendation by multi-criteria collaborative filtering and dimensionality reduction techniques. International Symposium on Nanoelectronic and Information Systems, pp. 231-236, 2016.

27. M. Hasan, S. Ahmed, D.M. Abdullah, M.S. Rahman. Graduate school recommender system: assisting admission seekers to apply for graduate studies in appropriate graduate schools. 5th International Conference on Informatics, Electronics and Vision, pp. 502-507, 2016. 